\title{
Problems Faced by Western Expatriate Managers in Eas- tern Europe: Evidence provided by Finnish Expatriates in Russia and Estonia*
}

\author{
Vesa Suutari $^{* *}$
}

A common human resource management strategy among Western companies in international operations is the use of home-country expatriate managers although expatriate adjustment has been found to involve difficulties. In the light of this the present study analyses the issues faced by Finnish expatriate managers working in Russia or Estonia. Three aspects were studied: adaptation to society, adaptation at the work place, and company-level management problems with which expatriates have to deal in their managerial job. The results indicate that various kinds of problems appear in all these areas and that the preparation of both expatriates and companies entering these markets was usually inadequate.

Eine unter westlichen Unternehmen alltägliche Personalmanagementstrategie ist der Einsatz von Managern aus dem Mutterland des Unternehmens, obwohl die Eingliederung von Mitarbeitern anderer Staatsbürgerschaft mit Problemen behaftet ist. Vor diesem Hintergrund analysiert die vorliegende Studie die Schwierigkeiten, denen finnische Manager bei der Arbeit in Rußland oder Estland begegnen. Drei Aspekten wurde dabei besondere Aufmerksamkeit gewidmet: Anpassung an die Gesellschaft, Anpassung an den Arbeitsplatz und Managementprobleme auf der Unternehmensebene; alles Probleme, mit denen ausländische Manager in ihrer Arbeit umgehen müssen. Die Ergebnisse der Studie zeigen, daß in allen diesen Gebieten verschiedenartige Probleme auftreten, und daß sowohl die Vorbereitung der Manager auf ihren Auslandseinsatz als auch die Vorbereitung der Unternehmen, die in diese Märkte eintreten, in der Regel unangemessen war.

Manuscript received: 10.09.97 revised: 13.01 .98 accepted: 05.02 .98

** Vesa Suutari, born 1967, Dr.Sc.(Econ.), Associate professor (act.) in Management and Organisation, University of Vaasa (Finland), Major areas of research interest: comparative management in Europe, expatriation across European borders and international human resource management. 


\section{Introduction}

The transformation of Central and East European societies has exerted tremendous adaptation pressures on local enterprises and individuals. Under the still relatively new market conditions there is an extensive need to develop managerial skills and thinking (see e.g. Garrison/ Artemyev 1994; Holt et al. 1994; Longenecker/Popovski 1994; Puffer/ McCarthy 1993; Wiley 1994). Recent surveys concerning Russian and Estonian managers indicate that local managers understand this (Avraamova 1995; Filatotchev et al. 1996; Üksvärav/ Nurmi 1993). There are similar problems concerning the attitudes, skills and organisational behaviour of local non-managerial employees who have learnt to work under different systems and rules than the ones applied under market conditions. Recent studies indicate that significant changes have already taken place although there is still a need for extensive transformation (Birch/ Pooley 1995; Filatotchev et al. 1996; Gurkov/ Kuz'minov 1995; Lipsitz 1995; Nurmi/ Üksvärav 1993).

Because of the pace of change, it has been commonly agreed that more information is needed on the experiences of both local and international organisations operating in Eastern Europe (e.g. Frese 1995; Grancelli 1995; Gurkov/ Kuz'minov 1995; Veiga et al. 1995:20; Welsh et al. 1993). After the opening of East European markets, the cross-border business interactions between Eastern and Western Europe have increased substantially. Thus, the understanding of the transformation needs of East-European enterprises has become important from a Western company point of view if they are to be able effectively to manage operations in Eastern Europe.

International business operations frequently face many difficulties due to crosscultural differences (e.g. Bleeke/ Ernst 1991; Olie 1990). The evidence of European cross-border acquisitions indicates that the acquisitions rated as not meeting their objectives had experienced unforeseen difficulties due to cultural differences in $90 \%$ of the cases studied (Norburn/ Schoenberg 1994). Frederick and Rodriques (1994:42) have stated that few Western managers dealing with acquisitions in Eastern Europe correctly anticipated the costs of restructuring and the difficulty of creating a business culture in formerly state-owned enterprises. It has also been stated for example that the interaction of Western managers and Russian employees is very problematic (Shekshnia 1994:298), and that Western managers in Russia often fail to deal with the cultural differences that lead to different interpretations of roles, responsibilities and goals (Veiga et al. 1995:20). Similarly, Suutari (1998) has reported that Western managers commonly face strong adaptation pressures to change their leadership style in Eastern Europe.

In the literature on international human resource management (IHRM), difficulties related to expatriation are commonly pointed out (see for example Black et al. 1991) although IHRM may still be regarded as a scientific field of study in its 
infancy (Welch 1994a:140). For example, a clear majority of expatriate adjustment studies have dealt with US expatriates and focused on cross-continental expatriation (Black et al. 1992:116). On the other hand, existing studies related to expatriation within Western Europe indicate that similar adjustment problems are usually faced also on such assignments (Brewster et al. 1993; Suutari/ Brewster 1998). Due to reported difficulties related to international assignments, a need for developing more effective expatriate management practices has been widely recognised.

On the other hand, the use of expatriates also brings clear benefits to the companies concerned and thus in many situations those are the best available options. The major benefits that expatriates may offer to international companies are control of foreign operations, integration and co-ordination of subsidiary practices in company policies, the transfer of organisational capabilities between organisational units, the effective communication between foreign operations and the home country, and the development of internationally competent managers. In addition, it is often difficult to find sufficient numbers of high-capacity local staff. Because of such problems, a so-called ethnocentric approach, i.e. the use of people from the home country in key positions in foreign organisational units (see Heenan/ Perlmutter 1979:18), is still widely resorted to among international companies as a basic human resource management strategy (Martinez/ Jarillo 1991; Welch 1994b).

For the same reason, also West European companies operating in Eastern Europe largely use expatriates in the management of their local operations. Still, the research on the adaptation problems faced by such expatriates has been scarce. This study therefore tries to increase understanding of the problems which Western expatriates face in two East European countries, i.e. Russia and Estonia. The objective of the study can be specified in the following question: What problems do Finnish expatriate managers face when working in Russia or Estonia? The problems which are faced will be studied at three different levels: a) problems related to the adaptation to the local community by expatriates (and their families), b) adaptation problems faced by expatriates at the work place, and c) additional company-level management problems which expatriates face in their managerial jobs.

\section{Expatriate adjustment}

Problems faced by expatriates during international assignments are dealt with in adjustment theories. One common model of international adjustment has been proposed by Black et al.(1991) on the basis of a literature review. In their model, the adjustment process has been divided into dimensions of adjustment to the general non-work environment, work responsibilities and intercultural interaction. The model distinguishes also more specific factors influencing adjustment. Non-work elements influencing the adjustment included two factors which were 
called family-spouse adjustment and culture novelty. Later, a social interaction factor has been proposed as an additional factor for the model (see e.g. Black/ Gregersen 1991; Kauppinen 1994). The second main element in the model, organisation culture, consisted of three factors: organisation culture novelty, social support and logistical help. Kauppinen (1994) has later suggested two additional factors influencing adjustment: perceived need for the expatriate by the host company and preparations for repatriation. The job environment element on the other hand consisted of four factors: role clarity, role novelty, role conflict and role discretion (Black et al. 1991). Black et al. have also included a fourth element in their adjustment model. This element, named "individual factors", included three subcategories: self-efficacy, relation skills, and perception skills.

As already stated in the introduction, there have only been a few studies on expatriation within Europe, but one recent study has been carried out by Suutari and Brewster (1998). That study indicated that difficulties were faced by expatriates within Europe in all three major areas of adjustment problems proposed in the model by Black et al. (1991). Starting from adaptation to social interaction, it was reported that problems were faced in the form of inadequate language skills and in the creation of contacts with local people. Adjustment problems appeared with regard to the general non-work environment also. Familyrelated problems in areas like social interaction, job availability for the spouse, schooling of the children, and health care systems were commonly reported. Difficulties with practical arrangements were also commonly faced - often in the form of difficulties in dealing with local authorities, in arranging suitable accommodation or in dealing with other arrangements necessary for daily life. Adaptation to work and job responsibilities was another issue. Adaptation problems which can be linked to 'organisation culture novelty' in the model by Black et al. (1991) were commonly reported. Because that factor was criticized as being a very broad factor a further differentiation of adaptation problems into three major groups was proposed by Suutari and Brewster: leadership styles, organisational systems and communication. Adjustment problems were commonly reported in all these areas. In addition, job environment related problems appeared in the form of inadequate role clarity, role novelty and role conflict between the local unit and the headquarters.

The above classifications of problems of adjustment and factors influencing it will be used as a framework in the analysis of research findings on issues faced by Finnish expatriates in Russia and Estonia. In addition to issues usually covered in studies on expatriate adjustment, the present study adopts a somewhat broader view by studying company-level management problems which expatriates face in their managerial jobs too. Thus, we are able to identify more clearly all the major difficulties faced by Western expatriates when working as managers in Russia and Estonia. 


\section{Characteristics of East European communities and organisa- tions}

This section of the paper provides a brief examination of East European environments and organisations in order to form a context-related preliminary view of the difficulties which may be faced by Western expatriates. Post-communist communities and organisations have been described as having characteristics which differentiate them from Western communities and organisations. Although many East European countries have their own history and culture, after half a century of Soviet domination they also have much in common due to similar requirements imposed by the Communist system. For example, Nurmi and Üksvärav (1993) have with regard to Estonia stated that the fifty-year Soviet legacy has left its marks on the attitudes of the Estonian people and on the organisational cultures of Estonian companies. Still, it is also clear that there are differences between ex-communist countries due to their different histories and national cultures.

According to Healey (1994:4) there have been many characteristics like the earlier central planning framework, nascent market systems, inflation, lack of fiscal discipline, and economic recession which East European communities have commonly shared. From the point of view of Western expatriates, it is obvious that the standard of living is still usually much lower in that area than in West European countries and thus one could expect expatriates to face problems related to the general non-work environment.

After the collapse of communism, East European economies have been unstable, which causes problems in managing business operations. With regard to local companies, the new environment of the enterprises has become much less protective, compared to the previous command economy situation (Grancelli 1995:5). Fey (1995) reports that problems caused by an unstable environment are also commonly faced by Western joint ventures in Russia. The various kinds of regulatory guidance existing in the market economies did not exist under communist rule; a huge number of new laws had to be developed. Because of this, Western companies - and the local ones - have to accept that the 'rules of the game' are frequently changing. For example, according to Kossov and Gurkov (1995:22) there have been some estimations that amendments to tax rules are made every two working days.

East European organisations have also been said to have many typical characteristics which differentiate them from West European companies. The increasing interest in East European markets has been reflected in many recent writings on management and organisation in Russia or Estonia (see e.g. Garrison/ Artemyev 1994; Ivancevich et al. 1992; Kozminski 1993; Liuhto 1991; Nurmi/ Üksvärav 1993; Pearce 1991; Rappoport et al. 1993; Shekshnia 1994; Suutari 1998; Vlachoutsicos/ Lawrence 1990). From such writings one can get a picture of organisations which are hierarchical, bureaucratic and centralised in comparison with 
Western companies (see e.g. Bollinger 1994; Garrison/ Artemyev 1994; Ivancevich et al. 1992; Kozminski 1993; Liuhto 1993b; Nurmi/ Üksvärav 1994). Technologies and machinery are often outdated and there is furthermore a lack of capital to carry out any needed changes.

From the point of view of leadership styles and management practices in Russia and Estonia, a major theme in the literature has been the discussion on the inadequate skills of local managers to manage business operations in a market economy. Even local managers have been reported to agree with this (Avraamova 1995:42; Filatotchev et al. 1996:94; Üksvärav/ Nurmi 1993:90). During the communist era the role of managers was mostly to solve daily operational problems (Puffer 1994:46). The leadership styles of managers in the East European area are commonly stated to be very authoritarian from a Western point of view (see e.g. Garrison/ Artemyev 1994; Puffer 1994). In a recent study it was reported that both Russian and Estonian managers are less active than their Finnish counterparts in most areas covered by Western leadership theories (Suutari 1998). Issues like a lack of open communication and initiation of new ideas and practices have also been commonly discussed elsewhere in the literature (see e.g. Ivancevich et al. 1992; Kozminski 1993; Lawrence/ Vlashoutsicos 1990; Longenecker/ Popovski 1994; Nurmi/Üksvärav 1994).

In addition to differences between typical East European and West European managers, it has been widely agreed that attitudes, skills and work behaviour of local employees differ clearly from their West European counterparts. Thus, effective human resource management has been stated to be a key issue in the successful transformation of East European organisations (see e.g. Frederick/ Rodrigues 1994; Gurkov/ Kuz'minov 1995; Ivancevich et al. 1992; Puffer/ McCarthy 1993; Shaw et al. 1991; Smith 1990). Similarly, in a survey concerning Russian managers, effective motivation of subordinates was considered a major concern (Ivancevich et al. 1992:47). A view one gets from the literature is that work morale and efficiency at the work place have been very low (see e.g. Birch/ Pooley 1995; Holt et al. 1994; Longenecker/ Popovski 1994). A lack of independent initiative and quality thinking, and low ethical standards have been frequently discussed (see e.g. Garrison/ Artemyev 1994; Grancelli 1988; Hertzfeld 1991; Kiezun 1991; Liuhto 1993b; Rapoport et al. 1993). Furthermore, overstaffing has been common because of the previous low level of efficiency and cost consciousness.

In the light of this, it is easy to predict that Western expatriate managers will face many difficulties because they have to deal with these differences across countries in order to be able to manage business units in Eastern Europe and to adapt themselves to the local community and organisation. 


\section{Methods}

The sample of the present study comprised 51 Finnish expatriates who were all working in Russia or Estonia. The study was carried out during 1996. 34 expatriates were interviewed and a further 17 expatriates responded to questionnaires. Due to the extensive transformation of East European economies, it was seen as necessary that the expatriates were working in their assignment during the time of the interviews and thus the interviews were carried out by telephone. The companies operated in a range of sectors of industry (metal, food, chemicals, paper, electrical products and instrument manufacturing, telecommunication, and machinery and equipment manufacturing). The expatriates were all Finns of an average age of 39.4 years. A clear majority of them were males $(69 \%)$ and had technical $(27 \%)$ or business education (61\%). Their international assignment had lasted 2.5 years on average and $49 \%$ of these expatriates were on their first assignment. All expatriates worked in managerial-level positions, as managing or vice managing directors, accounting managers, production managers and area managers.

During the interviews the expatriates were asked to talk freely about adaptation problems they had faced when they started work in a new country and in a new foreign organisational unit. Secondly, expatriates were asked to discuss company-level management problems faced by expatriate managers. They were also asked about preparation and the advice they would give to new expatriates on the basis of their experience. Open interviews were seen as the most appropriate research method because this allows the expatriates to talk freely about problems which they see as important. When questionnaires were used, the same questions were presented in a written form. Because the results of the two countries are mostly the same, they are presented together below. Where there are differences they will be noted.

There are inevitably several limitations to the present study. First, the number of expatriates is not large. Second, all the expatriates are Finns, which causes limitations to the external validity of the findings. Third, most expatriates were working in several major cities in Russia and Estonia, which are located near Finland. Because of these limitations, one should beware of making broad generalisations on the basis of the present findings, in particular with regard to Russia, which is an extensive country.

\section{Results: problems faced by Finnish expatriates and companies in Russia and Estonia}

In this section findings regarding adaptation problems reported by Finnish expatriates are presented. The presentation is divided into three sections. The first covers adaptation to the general non-work environment of society. Second, the adaptation at the work place is dealt with. Third, more general management 
problems faced by expatriate managers in Russia /Estonia are considered. The major problems reported by Finnish expatriates can be seen in Table 1.

Table 1: The major problems reported by Finnish expatriates working in Russia and Estonia

\begin{tabular}{|cc|}
\hline \multicolumn{2}{|c|}{$\begin{array}{c}\text { Percentage of respondents who re- } \\
\text { ported the problem in question }\end{array}$} \\
\hline A) General non-work environment \\
\hline $1 . \quad$ Practical arrangements & $78 \%$ \\
\hline 2. $\quad$ Family-spouse adaptation & $29 \%$ \\
\hline 3. $\quad$ Security issues & $22 \%$ \\
\hline 4. $\quad$ Social interaction & $16 \%$ \\
\hline 5. $\quad$ Culture novelty & $14 \%$ \\
\hline B) Work and job responsibilities & \\
\hline 1. Leadership styles & $79 \%$ \\
\hline 2. Organisational systems & $33 \%$ \\
\hline 3. Communication & $27 \%$ \\
\hline C) Major company-level management problems & \\
\hline 1. Frequent changes in legislation & $53 \%$ \\
\hline 2. Interaction with public authorities & $44 \%$ \\
\hline 3. Human resource management & $38 \%$ \\
\hline 4. Too optimistic expectations & $31 \%$ \\
\hline 5. Security issues & \\
\hline
\end{tabular}

As can be seen from Table 1, with regard to adaptation to the general non-work environment the most common problems faced were practical arrangements. This gives support to the importance of practical arrangements as a separate adjustment factor as was also seen in a study concerned with a West European context (Suutari/ Brewster 1998). Black et al. (1991) discuss logistical help and social support as factors influencing adjustment and thus the focus is more on the role of the company or host-country employees to help with these arrangements. Because of the lower standard of living, many expatriates reported diffi- 
culties in finding suitable accommodation. Availability of electricity, hot water and all kinds of services needed in daily life was found to be problematic although several expatriates also commented that the situation has improved in recent years, in Estonia in particular. About half the expatriate group reported that dealing with the public authorities was very difficult because of the extraordinarily high level of bureaucracy.

Problems related to family-spouse adaptation did not appear as commonly as in many other adaptation studies simply because few expatriates had brought their families with them. One of the major reasons for this was that Finland is located so near to the cities in Russia or Estonia in which expatriates worked that it was possible to visit Finland frequently. All the expatriates who had brought their families with them reported family adaptation problems. Typically those problems included inadequate language skills, lack of outside family contacts and security issues. Those who had their children with them stated that they had problems because there were not very many friends or playing fields for them. In some cases the children were of school-age and that had caused additional problems. However, in some cities like Tallinn and St. Petersburg there were Finnish schools, which made the situation a lot easier.

Security issues were often mentioned. Most expatriates talked about the stress which the fear regarding security caused, and in several cases real problems were also faced (for example, an armed robbery at home). Because security issues were so commonly mentioned they were classified as a separate adjustment factor in the present study. Inadequate language skills and problems in creating contacts with the locals were mentioned as problems related to social interaction. On the other hand, it should be taken into account that in Estonia one can manage with the Finnish language: which is of course a very important thing for expatriates. Furthermore, there are a lot of Finnish expatriates in Estonia to mix with and thus the need for local contacts may not be so extensive as is usually the case during expatriate assignments at least as far as personal comfort is concerned. With regard to Russia, almost all expatriates already had some kind of language skills in Russian. The social interaction factor was here included in the general non-work adjustment dimension although in a model by Black et al. (1991) it is presented as a third dimension of adjustment. This was done because expatriates were asked about adjustment to the general environment and at the work place as separate questions. Problems related to social interaction appeared in both cases, as will be shown later.

Furthermore, expatriates discussed at a more general level cultural differences which caused difficulties when one did not know for example how to act in different kinds of everyday situations. Several expatriates in Russia also mentioned that they had experienced a so-called culture shock during their assignment. Such difficulties can be linked to the culture novelty factor in the model by 
Black et al. (1991). In addition to these major problems, issues like pollution of the environment, the dirt of cities, and traffic problems were pointed out, but not frequently enough to be classified among the major adaptation problems.

Adaptation at the work place was another matter. Almost all the expatriates reported difficulties created by differences in leadership styles, hence supporting the identification of such a factor as a separate adjustment factor by Suutari and Brewster (1998). Two major issues were frequently pointed out. First, it was reported that expatriates were required to use a clearly more authoritative style than they were used to. It was commented for example that "one has to be tough and give direct orders", and that "one has to be extremely authoritative". Second, expatriates often mentioned the need continuously to supervise the work of local employees because otherwise it was not carried out in the required manner. For example, it was stated that "one has to supervise the work in every work phase", and that "a manager has to be present all the time because otherwise they start to do whatever they want". In addition to these major issues, it was reported for example that "one could not use team working with the locals". All these comments give support to the picture of leadership styles in Russia and Estonia presented in the literature (see e.g. Garrison/ Artemyev 1994; Liuhto 1991; Puffer 1994; Suutari 1998).

With regard to organisational systems, $31 \%$ of the expatriates reported difficulties. This supports the classification of such an adjustment factor as a separate factor. First of all, many expatriates stated that in local organisations there has been a very high level of formalization and thus the employees expect their job descriptions to be very clear and the limits of their responsibilities to be clearly defined. Expatriates state for example that "the work of employees has to be organised very specifically", and that "there has to be clearly defined tasks and rules". Second, it was reported that bureaucracy in the functioning of organisations was very marked. Third, it was commented that many functions common in the West (like marketing) have not appeared in East European organisations at all. Similarly, the tasks of the management group and the Board were unclear to the locals and had to be explained. All in all, the interpretation of tasks in general was totally different from Western approaches and caused communication and other problems. The evidence again supports the view given in the literature (see e.g. Bollinger 1994; Garrison/ Artemyev 1994; Ivancevich et al. 1992; Liuhto 1993b; Nurmi/ Üksvärav 1994; Suutari 1998).

Many expatriates had met difficulties due to differences in the mode of communication. This was not related only to inadequate language skills - other difficulties were also faced. First of all, in line with the comments presented in the literature (e.g. Ivancevich et al. 1992; Kozminski 1993; Lawrence/ Vlashoutsicos 1990; Longenecker/ Popovski 1994; Nurmi/ Üksvärav 1994; Suutari 1998), it was commented by many expatriates that the local communication style was not so open as that in Finland. Hence, it was not easy for expatriates to get into the 
organisation or to get the information they needed. The communication style in Estonia and Russia was less direct than in Finland. Furthermore, it was stated that it was very difficult to start a critical discussion of existing problems. Rather, expatriate managers had to identify problems by themselves and then order someone to take care of them in a defined manner.

Comments related to the job environment (i.e. role clarity / novelty / conflict / discretion) were not commonly reported although for example several comments related to role novelty did appear. This might be at least partly due to the fact that the expatriates stressed more the problems related to the lack of experience of locals with respect to organizational roles than problems related to their own role. In addition to the major groups of adaptation problems at the work place, several other issues were raised, though less frequently: the misuse of company property and involvement of employees with the black market, quality and efficiency problems, different ways of interpreting contracts, a fear among locals of contacting public authorities, and no strict adherence to timetables.

Company-level management problems in conducting business in Russia and Estonia were also explored in order to get a broader view of difficulties faced by Western expatriate managers. The most common difficulties at company level concerned frequent changes in legislation. The changes were reported to be so frequent that it was almost impossible to keep up with them. The laws and regulations are often very complex and it was hard to interpret them. This finding is in line for example with the finding by Fey (1995) regarding common problems in joint ventures in Russia. The second major area of problems was interaction with the public authorities. The public authorities are very bureaucratic. Expatriates reported for example that "you must have local people to help you with the bureaucracy", and that "it is very difficult to know where one can get information".

Expatriates also frequently reported problems related to human resource management. Human resource issues thus play a central role in the success of companies in Eastern Europe (e.g. Frederick/ Rodrigues 1994; Gurkov/ Kuz'minov, 1995; Ivancevich et al. 1992; Shaw et al. 1991; Smith 1990). In the present study, expatriates found it difficult to recruit employees with adequate professional skills. It was also commented that one should avoid recruiting local employees who are over 30 years old because they are too used to the traditional customs. Similar findings have been reported in the literature (Liuhto et al. 1993). On the other hand, other expatriates point out that age is highly respected in Russia, and that young people do not have the necessary personal contacts which are important in the local culture. The major differences between Finnish and local employees was reported as a lack of individual initiative among local employees. Local employees are not willing to take responsibility, their level of performance is low, and quality thinking is not common among them. Several expatriates also mentioned that local employees might have several jobs at the 
same time and that the stealing of company property was a common problem. All these observations give support to the picture presented in the literature (e.g. Gurkov/ Kuz'minov 1995; Liuhto 1993a; Puffer/ McCarthy 1993; Shaw et al. 1991). Because of these facts, the training needs of local employees were seen as extensive. Traditional training methods did not work with local employees, and expatriates were trying to develop more efficient ones.

Many Western companies in Russia and Estonia start with too optimistic expectations which are impossible to meet. Expatriates commented for example that " everything takes more time than expected", "the basic issues do not work out as easily as in Finland", and that "it takes clearly more time to start a business over here than expected". This causes extra pressures on the expatriates because often expectations from the headquarters were not realistic. Some expatriates argued that companies should be prepared to develop their business little by little and prepare themselves well for local markets before entering. With regard to security it was commented that expatriates should "prepare themselves well for security problems"; "stay in legal business only, because otherwise there will be problems with the Mafia"; and "check the background of business partners carefully".

In addition to these problems several other ones were mentioned occasionally. For example, it was stated that cultural differences are very difficult to deal with, and that promises are not kept equally well by business counterparts as in Finland. Lack of capital in Eastern Europe, eagerness of local shareholders to take the money out of a company as soon as possible rather than to invest it, and long payment times had also caused problems. The basic understanding of business principles is poor among local employees and planning and budget making is problematic because locals are not oriented to the future.

There were also some differences between expatriates' experiences in Russia and in Estonia that should be pointed out. First, expatriates in Estonia reported that things have developed quickly and circumstances do not any longer differ so clearly from Western ones as they used to do. Furthermore, the transformation within companies was stated to be quite rapid, although at the same time it was commented that it is difficult to get rid of old customs. A similar picture of quite rapid transformation in_Estonia has been reported by Nurmi and Üksvärav (1994:5).

\section{Conclusion and implications}

All in all, various problems were faced by Finnish expatriates in Russia and Estonia. The results of the study also indicated that previous classifications of expatriate adjustment, problems and factors influencing them, were found to be useful. In particular, when combined with existing knowledge of special characteristics of East European communities and organisations, the literature could 
provide a good preliminary understanding of problems faced by Western expatriates in Eastern Europe. The major problems were faced in the same areas as in a study concerned with the West European context. However, this does not mean that the problems were very similar although they were related to issues like leadership styles and organisational systems in both cases. In addition, some special characteristics like the frequent emergence of security issues appeared in the East European context.

One of the causes of the problems faced by expatriates themselves was inadequate preparation for the international assignment. In a similar manner, expatriates commented that the preparation made at company-level before entering Russian or Estonian markets was often inadequate and thus the expectations were reported to be too optimistic. Among the present expatriates, $62 \%$ thought that their preparation for the assignment was inadequate. Among those who considered that their preparation was sufficient the majority consisted of those expatriates who had earlier expatriate experiences $(40 \%$ of the expatriates had such experience) and / or longer prior experience of East - European markets. When some preparation was received, a prior visit to the foreign unit $(50 \%)$ and language training $(41 \%)$ were the most common forms of preparation. 25 per cent of the expatriates had also sought information on their own initiative, most often from the literature. Job-related training had been received by every third expatriate, and country-/ culture-related training only by 13 per cent of the expatriates. Almost half of the expatriates (42\%) left for their international assignment without any preparation at all. Several expatriates were quite pessimistic about the possibilities of receiving relevant training before assignments, because very few Western people have the necessary understanding of Eastern Europe to provide up-to-date training.

As the results of the present study indicate, Eastern Europe is not an easy area for Western expatriates. In order to be able to help new expatriates to learn from the experiences of previous ones, the expatriates were asked what kind of advice they would give to a new expatriate going to Eastern Europe. The results can be compared with findings from expatriation within the West European context (Suutari/ Brewster 1998) in order to discover some special features of Russian and Estonian markets from the point of view of Western expatriates. The most commonly given bits of advice are presented in Table 2 .

As can be seen from the table, the most commonly given piece of advice was related to the need to be patient and have a high level of tolerance. This finding is clearly related to the specifics of East European markets, because it was not reported in the study within West European expatriation. Expatriates offered comments like "try to be very patient because everything takes so much time"; "try to stay calm even when issues don't go like you planned"; and "be prepared for hard work, because it takes a long time before any results are achieved". It was 
also commented that expatriates should be very flexible and tolerant of stress, and that this should be taken into account when expatriates are selected.

\section{Table 2: Expatriates' advice to future expatriates}

1. Be patient and have a high level of tolerance

2. Acquire good language skills beforehand

3. Obtain knowledge of the country and its culture and history

4. Be careful concerning security issues

5. Try to adapt your thinking and behaviour to local customs

6. Don't go to Eastern Europe as "a great Western master"

7. Discuss with earlier expatriates

8. Make a prior visit to the country / organisation

9. Take care of your family during the assignment

10.Make sure that you have good professional skills in your new job

About half of the expatriate managers also stressed the need for acquiring good language skills beforehand and for obtaining prior knowledge of the characteristics of the local community and culture. These comments are in line with findings in earlier expatriate research. A second commonly offered piece of advice which did not appear in the study within the West European area, was the importance of security. It was commented that "one should take care of security issues as well as possible", and that "companies should formulate specific security rules for their employees both for work time and free time".

The fifth most commonly given piece of advice was that expatriates should actively try to adapt their own thinking and behaviour so that it is appropriate for an East European context. Thus, the picture is partly similar to that which emerged in the study of Western-Europe expatriation. In the present study expatriates stated that "Finnish models cannot be applied in the East European context as such"; that "one must also himself be prepared to adopt his working style and not just expect locals to adapt their styles"; and that "one has to be prepared to adapt himself also and to respect the local system". It was also stated that "cultural differences are so extensive that it takes two thirds of our energy to cope with those and thus it leaves only one third for work".

A third distinctive piece of advice to new expatriates when compared to findings from the West European context, was the suggestion that expatriates should not be arrogant and behave as if they were the only ones who knew how things should be carried out (i.e. one should not behave like a great Western master). 
For example, one expatriate said that "Russian people are not always willing to adopt Western methods but would rather like to develop their own applications of such methods". Furthermore, expatriates commented that "many Western businessmen do not honour local manners at all and insult local people, but one should not behave in that manner because they will remember it for a long time". This supports the view by Holt et al. (1994:137) who have commented that the Russians do not for example adopt Western practices easily without testing and resistance (see also Frederick/ Rodrigues 1994:46; Holt et al. 1994:137; Shekshnia 1994).

The rest of the advice was similar to that reported in a study by Suutari and Brewster (1998). One should consult with expatriates who have earlier worked in the country in question, make a prior visit to the country in order to get things arranged, take good care of ones family during the assignment, and take care that one has good professional skills for the new job. Among those who brought their family with them, the importance of family-related preparation and arrangements was frequently mentioned. Other advice includes "create good connections with important locals because personal relationships are here very important when doing business", "be careful with taxation issues", "take care of repatriation issues beforehand", and "have realistic objectives from the beginning".

Looking at these comments and the results of the study from a company point of view, many implications appear. First, clearly most expatriates felt that their training was inadequate and thus they had faced more problems than would have been necessary. This is supported by a review of studies on expatriate training because it was found that training had been considered useful when received (e.g. Black/ Mendenhall 1990). Expatriates' advice presented in Table 2 points to other specific areas which companies could take into account in their expatriate management practices, and indicates several special characteristics of East European environments as compared with West European environments. The results also indicate many common company-level management problems in operations in Eastern Europe. These findings should help companies to know more about what to expect and to prepare themselves better for operations in Eastern Europe. As many expatriates commented, Western companies' expectations are usually too optimistic. For example, the training needs of local employees are extensive and time consuming. Recruiting employees was described as one area in which companies should be very careful. Furthermore "companies should be prepared to meet surprises related to personnel issues". The importance of good preparation for security issues also appeared frequently both at individual and company level. 


\section{Acknowledgements}

The author would like to thank Pasi Jokela for research assistance and the Academy of Finland for financial support.

\section{References}

Avraamova, E. (1995): Russian Elites amid Social and Economic Reforms. In: International Studies of Management \& Organisation, No. 25(4), pp 9-26.

Birch, N./ Pooley, J. (1995): Changes in Russian Quality Management Practices from 1989 to 1992. In: Management International Review, No. 35(3), pp 219-239.

Black, J.S./ Gregersen, H.B. (1991): The Other Half of The Picture: Antecedents of Spouse Cross-Cultural Adjustment. In: Journal of International Business Studies, No. 22(3), pp 461-477.

Black, J.S./ Gregersen, H.B. / Mendenhall, M.E. (1992): Global Assignments: Successfully Expatriating and Repatriating International Managers, San Francisco.

Black, J.S./ Mendenhall, M. (1990): Cross-Cultural Training Effectiveness: A Review and a Theoretical Framework for Future Research. In: Academy of Management Review, No. 15(1), pp 113-136.

Black, J.S./ Mendenhall, M. / Oddou, G. (1991): Toward a Comprehensive Model of International Adjustment: An Integration of Multiple Theoretical perspectives. In: Academy of Management Review, No. 16(2), pp 291-317.

Bleeke, J./ Ernst, D. (1991): The Way to Win in Cross-Border Alliances. In: Harvard Business Review, No. November, pp 127-135.

Bollinger, D. (1994): The Four Cornerstones and Three Pillars in the "House of Russia" Management System. In: Journal of Management Development, No. 13(2), pp 49-54.

Brewster, C./ Lundmark A./ Holden L. (1993): 'A Different Tack' - An Analysis of British and Swedish Management Styles, Lund.

Fey, C. (1995): Important Design Characteristics for Russian - Foreign Joint Ventures. In: European Management Journal, No. 13(4), pp 405-415.

Filatotchev, I./ Hoskinsso, R.E./ Buck, T./ Wright, M. (1996): Corporate Restructuring in Russian Privatizations: Implications for U.S. Investors. In: California Management Review, No. 38(2), pp 87-105.

Frederick, W.R./ Rodrigues, A.F. (1994): A Spanish Acquisition in Eastern Germany: Culture Shock. In: Journal of Management Development, No. 13(2), pp 42-48.

Frese, M. (1995) Entrepreneurship in East Europe: A General Model and Empirical Findings. In: Cooper, C.L./ Rousseau D.M.: Trends in organisational Behaviour, Volume 2, Chichester.

Garrison, T./ Artemyev, A. (1994). Managing People in Russia. In: Garrison, T./ Rees, D.: Managing People across Europe, Oxford.

Grancelli, B. (1988): Soviet Management and Labour Relations. Boston. 
Grancelli, B. (1995): Organizational Change: Towards a New East-West Comparison. In: Organization Studies, No. 16(1), pp 1-25.

Gurkov, I./ Kuz'minov, Y. (1995): Organizational Learning in Russian Privatized Enterprises. The Beginning of Strategic Change. In: International Studies of Management \& Organization, No. 25(4), pp 91-117.

Healey, N.M. (1994): Doing Business with Eastern Europe: A Situational Analysis. In: European Business Review, No. 94(3), pp 3-8.

Heenan, D.A./ Perlmutter, H. (1979): Multinational Organization Development, Reading, Mass.

Hertzfeld, J.M. (1991): Joint Venture: Surveying The Soviets from Perestroika. In: Harvard Business Review, No. 69(1), pp 80-91.

Holt, D.H./ Ralston, D.A./ Terspstra, R.H. (1994): Constraints on Capitalism in Russia: The Managerial Psyche, social Infrastructure, and Ideology. In: California Management Review, No. 36(3), pp 124-141.

Ivancevich, J.M./ DeFrank, R.S./ Gregory, P.R. (1992): The Soviet Enterprise Director: An Important Resource Before and After the Coup. In: Academy of Management Executive, No. 6(1), pp 42-55.

Kauppinen, M. (1994): Antecedents of Expatriate Adjustment - A Study of Finnish Managers in the United States, Licentiate Thesis in Management, Helsingin Kauppakorkeakoulun julkaisuja B-140, Helsinki.

Kiezun, W. (1991): Management in Socialist Countries: USSR and Central Europe, Berlin.

Kossov, V./ Gurkov, I. (1995): The System of Management in Modern Russia Legacy of the Command Economy and Current Transformations. In: International Studies of Management \& Organization, No. 25(4), pp 9-25.

Kozminski, A.K. (1993): Catching up ? Organizational and Management Change in the ExSocialist Block, New York.

Lawrence, P.R./ Vlashoutsicos, C.A. (1990): Behind the Factory Walls: Decision Making in Soviet and US Enterprises, Boston.

Lipsitz, I. (1995): Russian Managers under Conditions of Reform and Crisis. In: International Studies of Management \& Organization, No. 25(4), pp 77-90.

Liuhto, K. (1991): The Interaction of Management Cultures in Soviet-Finnish Joint Ventures, Turku School of Economics and Business Administration, Turku.

Liuhto, K. (1993a): Creating New Managerial Concept to Replace Management Sovieticus: Managerial Transformation in Eastern Europe and in the Former Soviet Union, Serie B4, Turku School of Economics and Business Administration, Turku.

Liuhto, K. (1993b): Tie menestykseen Venäjän lähialueilla: Suomalaisten yhteisyritysjohtajien kokemuksia liikkeenjohtamisesta Pietarissa, Petroskoissa ja Murmanskissa, Serie B, Reports 1/93, Turku School of Economics and Business Administration, Turku.

Liuhto, K./ Akhobadze, D./ Samokhin, Y. (1993): St. Petersburg Business Guide: Information and Recommendations for Foreign Companies, Turku School of Economics and Business Administration, Turku. 
Longenecker, C.O./ Popovski, S. (1994): Managerial Trials of Privatization: Retooling Russian Managers. In: Business Horizons, No. 37(6), pp. 35-43.

Martinez, J.I./ Jarillo, J.C. (1991): The Evolution of Research on Co-ordination Mechanism in Multinational Corporations. In: Journal Of International Business Studies, No. 20(3), pp 489-514.

Norburn, D./ Schoenberg, R. (1994): European Cross-Border Acquisitions: How Was It for You? In: Long Range Planning, No. 24(2), pp 25-34.

Nurmi, R./ Üksvärav, R. (1993): How Estonian Managers Experienced the Transformation to Independence and Market Economy in 1990-1991. In: Management International Review, No. 33, pp 171-181.

Nurmi, R./ Üksvärav, R. (1994): Estonia and Finland: Culture and Management, A Conjectural Presentation, Publication Series A-9:1994, Turku School of Economics and Business Administration, Turku.

Olie, R.L. (1990): Culture and Integration Problems in International Mergers and Acquisitions. In: European Management Journal, No. 8(2), pp 206-215.

Pearce, J.L. (1991): From Socialism to Capitalism: The Effects of Hungarian Human Resources Practices. In: Academy of Management Executive, No. 5(4), pp 75-88.

Puffer, S.M. (1994): Understanding the Bear: A Portrait of Russian Business Leaders. In: Academy of Management Executive, No. 8, pp 41-54.

Puffer, S.M./ McCarthy, D.J. (1993): Soviet Managers View Organizational Change in Large State Enterprises. In: Journal of Organizational Change Management, No. 6(3), pp 623.

Rapoport, V.S./ Ryssina, V./ Umpleby, S.A./ Halal, W.E. (1993): Commonwealth of Independent States. In Peterson, R.B.: Managers and National Culture - A Global Perspective, Westport.

Shaw, J.B./ Fisher C.D./ Randolph, W.A. (1991): From Materialism to Accountability: The Changing Cultures of Ma Bell and Mother Russia. In: Academy of Management Executive, No. 5(1), pp 7-20.

Shekshnia, S. (1994): Managing People in Russia: Challenges for Foreign Investors. In: European Management Journal, No. 12(3), pp 298-305.

Smith, H. (1990): The New Russians, New York.

Suutari, V. (1998): Leadership Behaviour in Eastern Europe: Finnish Expatriates' Experiences in Russia and Estonia. In: The International Journal of Human Resource Management, No. 9(2), pp 237-260.

Üksvärav, R./ Nurmi, R. (1993): Estonian Economy and Management in the Early 1990's, Publication Series A-4:1993, Turku School of Economics and Business Administration, Turku.

Veiga, J.N./ Yanouzas, J.N./ Buchholtz, A.K. (1995): Emerging Cultural Values in Russia: What Will tomorrow Bring? In: Business Horizons, No. July/August, pp 20-27.

Vlachoutsicos, C./ Lawrence, P. (1990): What We Don't Know about Russian Management. In: Harvard Business Review, No. 68(66), pp 50-63. 
Welsh, D.H.B./ Sommer, S.M./ Birch, N. (1993): Changing Performance among Russian Retail Workers: Effectively Transferring American Management Techniques. In: Journal of Organizational Change Management, No. 6, pp 34-50.

Welch, D. (1994a): Determinants of International Human Resource Management Approaches and Activities: A Suggested Framework. In: Journal of Management Studies, No. 31(2), pp 139-164.

Welch, D. (1994b): HRM Implications of Globalization. Journal of General Management, No. 19(4), pp 52-68.

Wiley, D.L. (1994): Developing Managers in the Former Soviet Union. In: International Studies of Management and Organization, No. 24(4), pp 64-82. 